\title{
Más allá de los muros. Historias de mujeres dentro (y fuera) de prisión
}

Frois, Catarina. 2017. Mulheres Condenadas. Histórias de dentro da prisão. Lisboa: Tinta da China.

La lectura de Mulheres Condenadas. Histórias de dentro da prisão lleva de la mano al interior de una pequeña cárcel de mujeres en una tranquila localidad portuguesa. La etnografía que presenta Catarina Frois permite adentrarse en la vida cotidiana que se desarrolla tras los muros y tras la rutina, no siempre rutinaria, de una de las instituciones totales más denostadas por la literatura académica, evidenciando claroscuros y ambigüedades. Además, y en la misma línea que ya han desarrollado otras autoras (Cunha, 2002), establece vínculos más allá de los muros, haciéndose eco de la vida de las mujeres reclusas y sus circunstancias antes de entrar en prisión, poniendo así de manifiesto estructuras de institucionalización de la exclusión.

Mi intención con esta reseña es argumentar por qué, en mi opinión, las personas interesadas en prisiones deberían leer este libro. Mi primera razón tiene que ver con el hecho de que ofrece un acercamiento poco común a un establecimiento penitenciario. Su trabajo huye de abstracciones y aterriza en lo concreto, de modo que al leer se siente una suerte de inmersión en el texto y en el contexto en el que se inspira. En segundo lugar, ofrece un elemento comparativo de gran utilidad en este ámbito de trabajo, no sólo porque la mayoría de la producción sobre las prisiones proviene de disciplinas como la criminología y la psicología, sino, además, porque este tipo de estudios suele centrarse en ámbitos anglosajones (Moore y Scraton, 2014; Jewkes, Bennet y Crewe, 2016). En tercer lugar, el trabajo se desarrolló en una prisión muy particular y eso, unido a la antropológica mirada de la autora, permite profundizar en cuestiones importantes del debate sobre las instituciones penales, e incluso ahondar en cuestiones éticas y metodológicas de nuestra disciplina. Por último, porque no se puede perder de vista la importancia de que esta investigación se centre en una prisión de mujeres cuando la mayor parte de la producción académica sobre el tema se centra en cárceles de hombres. Esto permite no sólo un análisis en términos comparativos, sino poner sobre la palestra cuestiones de género que, de ser tenidas en cuenta, podrían facilitar el camino hacia un sistema judicial y penal menos discriminatorio, si es que esto fuera posible.

En mi opinión, uno de los mayores desafíos a los que se enfrenta la investigación antropológica en las prisiones es producir etnografías en las que la ambigüedad y especificidad de estos espacios cobre relevancia. Como ya he señalado, la mayor parte de las investigaciones en prisiones se desarrollan desde disciplinas como la criminología y psicología que, si bien resultan muy enriquecedoras y necesarias, suelen partir de miradas condenatorias y centradas en los efectos negativos que estas instituciones conllevan y producen, en una suerte de alineamiento con lo que Orland (1975) denominó Houses of Darkness. Sin dejar la profunda crítica de lado, Frois aboga por una mirada en la que, a riesgo de presentar un escenario "demasiado idílico" (p. 66), pone de manifiesto las particularidades de 
la prisión en la que desarrolló su trabajo de campo etnográfico. Así, presenta una cárcel en la que, más allá de las siempre presentes relaciones de poder, se podían establecer lazos de cordialidad e incluso de afecto. Poner en evidencia las fisuras en la supuesta rigidez en las relaciones entre vigilantes y vigiladas supone poner en evidencia las contradicciones y claroscuros existentes en cualquier contexto social, prisiones incluidas.

Ambigua o no, la vida en prisión no es fácil y el día a día se desenvuelve en una rutina que cambia a lo largo del año y que responde a la idiosincrasia de la institución. Para conseguir transmitir la ambigüedad y especificidad de la cárcel, la mirada de la autora se nutre de conversaciones y de mucho tiempo compartido con las mujeres que cumplían condena. Así, y en relación a cuestiones metodológicas, es posible que una de las bazas de esta investigación haya sido la predisposición de la directora de la cárcel para con el trabajo de la autora. Sin horas de entrada y salida, pudiendo grabar todas las conversaciones y con permiso para fotografiar la prisión, la minuciosidad recreada en las historias de vida de las internas y la cotidianidad plasmada en imágenes, produce un efecto de cercanía no siempre fácil de conseguir.

Pero las vidas y las interpretaciones de las mujeres sobre sus propias experiencias no sólo permiten acercarse a la prisión, sino que transportan más allá de sus muros y así, con historias que reflejan situaciones de desigualdad mantenidas en el tiempo, es como Frois asegura que muchas de las mujeres ya estaban cumpliendo condena aun estando en libertad. Poniendo sobre la mesa, incluso, la crudeza de trayectorias marcadas por delitos de sangre y/o malos tratos continuados, tanto recibidos como infligidos, la autora presenta, siempre a partir de las narraciones de las mujeres, los vericuetos de un sistema judicial que no sólo basa su (in)justicia en leyes penales sino también morales. Porque no cumplir con el rol establecido por la sociedad, ser [buena] Mulher, esposa, mãe, es lo único que quizá no se pueda condonar. Tal y como señala Frois, el "deber ser" también marcaba los ritmos de higiene cotidiana de la prisión. De este modo, muestra cómo las mujeres reclusas interiorizaban el deber moral de la "buena presencia", al punto de reprochar las conductas no higiénicas a aquellas que se atrevieran a romper las reglas. Así, a través de estos senderos de interiorización del "deber", las mujeres trazaban la línea entre una vida - fuera — ligada al crimen y una vida - dentro- de redención.

Estas ideas están relacionadas con la intención de la autora por demostrar, a partir de historias de vida concretas, la institucionalización de la exclusión. De este modo, acompañamos a Filipa en lo que Frois denomina una versión kafkiana de vida, relatando un camino vital en el que una niña considerada "vulnerable" por los servicios sociales portugueses pasó a ser condenada, tiempo después, a prisión. Tal y como la autora explica: "De relatório em relatório, de avaliação em avaliação, foi-se criando uma imagem de Filipa, num retrato que clama por "intervenções", que faz diagnósticos, até que em ultima instancia se considera que só em meio fechado é possível atuar" (p. 200). Paradójicamente, y a partir de historias marcadas por la institucionalización, la autora se pregunta si las prisiones pueden convertirse en lugares en los que encontrar cierta estabilidad, mientras que pone sobre la mesa de debate una de las cuestiones más espinosas sobre la finalidad de estas instituciones: ¿hasta qué punto puede, o debe, entenderse el encarcelamiento como una ramificación de los servicios sociales del Estado? Contestar a esta pregunta supone dejar al descubierto tanto las inconsistencias del sistema penitenciario - portugués, en este caso-como 
la ineficacia del Estado de bienestar, puesto que: "Quando fossem libertadas, a sua precariedade e pobreza estaria agravada, na mesma medida em que estariam reduzidas as possibilidades de encontrar um trabalho, agora ainda mais dificultado pelo registo criminal" (p.234).

Una de las cuestiones más interesantes, pero quizá menos tratada en el libro es la relacionada con los dilemas y compromisos éticos y metodológicos. No obstante, la obra ofrece suficientes situaciones como para reflexionar sobre estos temas, no sólo en relación a la investigación en prisiones sino en relación a toda investigación antropológica. Como tantas de nosotras, Catarina Frois se vio confrontada con la finalidad de su presencia en la prisión: "Mas afinal de que é que nos serve esse livro que a senhora anda a escrever? A gente o que precisa é de oportunidades, não é de livros" (p.234). Su rol de investigadora se vio rebasado por las circunstancias y las vivencias, convirtiéndose en consejera de las internas que buscaban, por iniciativa propia o por consejo de las funcionarias de vigilancia, consuelo en ella: "Quando queriam «desabafar», eu parecia ser uma opção tão boa como qualquer outra, ou talvez até melhor, em sua opinião. Explicavam-me que era «bom falar com alguém de fora», alguém que não fosse nem «colega», nem guarda prisional” (p.144). Y, por último, lejos de huir de las contradicciones del discurso en la comunicación entre diferentes colectivos en prisión, la autora opta por una perspectiva que asume que la vida cotidiana de todas estas personas, en especial la de las reclusas, se encontraba en la prisión y que, por tanto, como en cualquier otro contexto, esta cotidianidad está plagada de contradicciones. Es desde este prisma, reconociendo la cárcel como un contexto especial pero cotidiano para sus habitantes, desde el que debemos acercarnos a las investigaciones en establecimientos penitenciarios. De otro modo, la mirada siempre quedará velada por estereotipos y procesos de "otrización”. Y puesto que este es el prisma que adopta la autora, su obra irradia respeto hacia las mujeres que participaron de su investigación.

En definitiva, la autora presenta una obra en la que la recreación de historias de vida de mujeres en prisión, con sus luces y sombras, con la descripción de momentos de angustia y enfrentamiento, pero también de momentos de sosiego, pone sobre el tapete la importancia de acercar una mirada crítica que destape las ambigüedades, crudezas y pequeños destellos de una institución que confronta a cada sociedad con sus propias limitaciones y procesos de desigualdad.

Carmen Osuna

UNED

cosuna@fsof.uned.es

\section{Referencias bibliográficas}

Cunha, Manuela (2002). Entre o Bairro e a Prisão. Tráfico e Trajectos. Lisboa: Afrontamento. Moore, Linda; Scraton, Phil (2014). The Incarceration of Women. Punishing Bodies, Breaking Spirits. Londres y Nueva York: Berghahn.

Orland, Leonard (1975). Prisons: Houses of Darkness. New York : The Free Press.

Jewkes, Yvonne; Bennet, Jamie; Crewe, Ben (Eds.) (2016). Handbook on Prisons. Oxon y Nueva York: Routledge. 